\title{
Developing Interactive Teaching Material to Increase Students' Understanding about the Concept of Audit Practice
}

\author{
Muhammad Ridha Habibi $Z^{1 *}$, Taufik Hidayat ${ }^{2}$, and Nisha Marina ${ }^{3}$ \\ Department of Accounting, Universitas Negeri Medan, Indonesia ${ }^{1,2,3}$ \\ *mridhahabibi@unimed.ac.id
}

\begin{abstract}
One of the abilities that must be mastered by the students in learning the audit practice is to understand the concept of accounting checks in solving a case. To realize this goal, a lecturer must have skills in choosing the proper methods and making new innovations to create an effective and efficient learning environment for students. The Financial Professional Development Center (PPPK) of the Ministry of Finance and the Indonesian Institute of Certified Public Accountants (IAPI) developed ATLAS (Audit Tool and Linked Archive System) electronic application on 2018. It facilitates the process of preparing audit worksheet in the Public Accountant Office. The use of proper learning methods and teaching materials will influence the learning process in the classroom to be more attractive. To find out the effectiveness of the learning process with this method statistically, a regression analysis was carried out, in addition to qualitative analysis. The results of the pretest and posttest were respectively 73.36 and 90.57. Based on the above calculation, the gain score obtained from the comparison of the average value of pretest and posttest in learning using interactive teaching materials is 0.65 with the category "Medium" (0.7 N-Gain> 0.3). The increasing of post-test mean scores indicates that interactive teaching materials have been able to enhance the student's understanding of audit practice in general after the students use ATLAS for learning.
\end{abstract}

Keywords: Audit Practice, ATLAS, Learning Effectiveness.

\section{Introduction}

Quality assessment of educational products is first seen in the development of basic attitudes, such as scientific academic stance and continuing willingness to seek truth. Therefore, the concept of education is not reduced on exams that only measure knowledge transfer, but it is wider, including the establishment of skills and basic attitude, such as critical thinking, creativity and openness to innovations and inventions. Audit practice is one of the subjects learned in college. The Students must be able to understand the concept of audit practice, explaining the relationship between concepts and implementing the concept accurately and efficiently in problem solving.

Therefore, this should be supported by the effectiveness of the interactive methods of learning and teaching materials. So far, the existing teaching materials are often not interactive and incomplete. It is required that a teaching material is capable of explaining the material in more detail, visualizing abstract material, and training students to think creatively in order to solve the cases. 
The Financial Development Center (PPPK) of the Ministry of Finance and the Institute for Public Accountants (IAPI) developed the electronic application ATLAS (Audit Tool and Linked Archive System). Responding to this, ATLAS was chosen to be used in the study of accounting practice. The effectiveness of media use and modules will be seen from student enthusiasm in the learning and teaching process.

\section{Theoretical Framework}

Learning is the process of acquiring knowledge and science, forming attitudes, habits and beliefs with the help of teachers in a learning environment [1]. Teaching materials are one of the important supporting factors in learning. The use of teaching materials can improve student learning outcomes. In drafting the teaching materials at least the following four elements, namely (1) there is content or subject matter (2) using the media, (3) arranged with the intention of assisting students in learning and achieving learning objectives, and (4) the existence of instructions for use.

The type of teaching materials divided into two namely (1) printed teaching materials in the form of handouts, textbooks, modules, programed materials, (2) Electronic teaching materials in the form of interactive CDS, TV, and radio. Teaching materials can also be tapes, videos, CD-rooms, dictionaries, reading books, photographs, newspapers, etc. The module can be divided into two types or shapes, and Figure 1 shows the description in more detail.

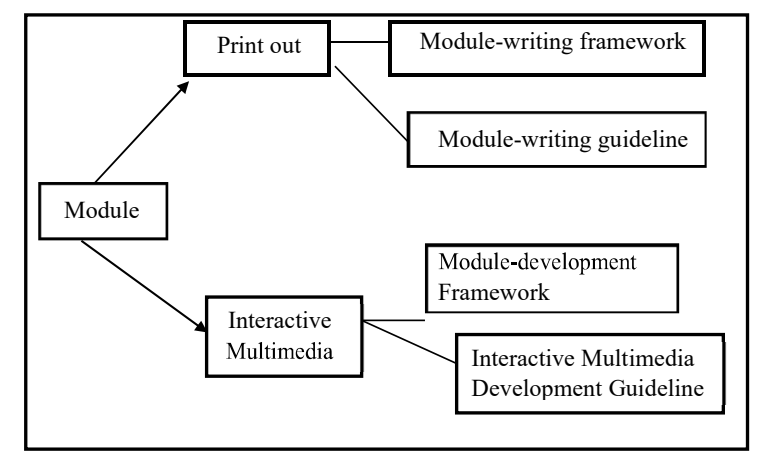

Fig 1. Type of modules

An interactive learning method is a teaching strategy that emphasizes common attitudes or behaviors in working or assisting among others in the working structure In a group, consisting of two or more people. Work success is heavily influenced by the involvement of each member of the group. Interactive learning is a type of learning that prioritizes the cooperation between students to reach the learning objectives. The learning step is as follows: (a) convey purpose and motivate students; (b) Provide information; (c) Organizing students in study groups; (d) Guiding study and work groups; (e) Evaluation; (f) Give awards.

\section{Research Method}

The used research method is R \& D (Research \& Development), which is oriented to researching, designing, producing, testing, and validating the produced product. The development model used in this study is a model developed by M. Alessi and Stanley R. 
Trollip, which consists of stages of planning (planning), design (design), and development (development).

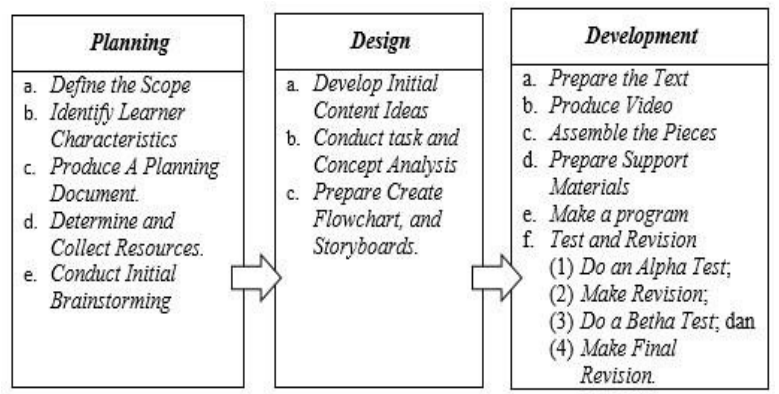

Fig 2. The stages of development model

\subsection{Planning Stage}

a. Define the Scope.

At this stage, we determine the material raised and determine the achievement target. Identify Learner Characteristics. In identifying the characteristics of the product users used as a target of interactive teaching materials development using interview techniques with lecturers and students. The target (user) of the interactive teaching materials product in this study is student of VII semester in Accounting Department.

b. Produce a Planning Document.

Before developing a product, it is recommended to create a planning document that contains material, images, animations, test scripts, product views, which are presented in a teaching material.

c. Determine and Collect Resources.

At this stage, covers all materials used to support and assist in the process of product development. There are three sources of materials used in this development: (1) everything that is relevant to the material presented. (2). All that is relevant to the development and process of learning. (3). All relevant in accordance with the conveyance techniques presented in the interactive teaching materials are the software used. The source is used based on SK and $\mathrm{KD}$ which is contained in the syllabus and is equipped with other references that are suitable for the purpose of learning.

d. Conduct Initial Brainstorming.

Brainstorming is done with the professor of Accounting Practice examination related to the interactive teaching materials of accounting check practices that will be developed to add insight.

\subsection{Design Stage}

a. Develop Initial Content Ideas.

At this stage, the researcher designs the initial content contained in interactive teaching materials such as the theme of interactive teaching materials, the type of color and size of the text.

b. Conduct task and Concept Analysis.

At this stage, the purpose of the task analysis is to determine the order of the material using concept maps so that they are easy to learn by students. Whereas concept analysis is focuses on how to organize the material so that it is easily seen.

c. Prepare Create Flowchart, and Storyboards. 
The last stage in the design phase is making flowcharts and storyboards that are used as guidelines for the development of teaching materials from the aspects of appearance, navigation, layout, and material presented to achieve learning objectives.

\subsection{Development Stage}

a. Prepare the Text

Prepare the text of the material presented in interactive teaching materials. The text of this material is adapted to the syllabus and Learning Implementation Plan (RPP).

b. Produce Video

Interactive teaching materials developed will be equipped with videos that explain the material and discussion of the questions. The video presented is in the form of a brief explanation of the material.

c. Assemble the Pieces

At this stage merge all content into one file in the form of text, images, animation, and video. Prepare Support Materials, in addition to media content in the form of text, images and videos will also be equipped with other supporting materials such as animations and user manuals, so the teaching material developed is interactive and easy to use.

d. Test and Revision

At the test and revision stage has the following steps, consisting of: (1) Do an Alpha Test; (2) Make Revision; (3)Do a Beta Test; and (4); Make Final Revision. The alpha test will be validated by media experts and material experts and the beta test was conducted on 34 semester VII students.

\subsection{Product trial design}

Trial Design

Product trials conducted in this study aim to collect data about the quality of the product to be used. Interactive teaching material products in the form of interactive learning modules will be more quality if tested and revised. The module product trial phases conducted in this study are:

a. Alpha Test

At this stage, the interactive teaching material products that are developed will be validated by two media experts and two material experts who master their fields using instruments that have been prepared previously. Furthermore, revisions were made according to the input of the two experts. If the content experts and media experts have agreed to the revised results, then proceed to the beta test.

b. Beta Test

Beta test is done after alpha test is given. The beta test consists of two stages, namely beta 1 and beta 2 . Beta 1 is given to a small group of students. In order not to be biased, this small group test will be tested on VII semester students who have taken accounting examination -1 and examination of accounting- 2 courses, while beta test 2 is given to large groups of students meaning it is given to 34 students majoring in accounting FE-Unimed as research subjects. The purpose of this beta test is given to determine student responses about the interactive teaching material products used. After the student response instrument is obtained, the next step of the data is processed and analyzed. In the beta test 2 also tested the effectiveness of the product through pretest and posttest. 


\section{Trial subject}

The experimental subjects in this study were material experts, media experts, and VII semester students of the Accounting Department FE-Unimed 2019/2020 school year. Material experts and media experts play a role in assessing the feasibility of the report. Many trial subjects in the first beta test were 7 semester VII students while the total numbers of trial subjects in the beta test were 28 students consisting of VII semester students.

\section{Data collection technique}

Data collection techniques used in this study were questionnaires, tests, interviews and observations. The instruments used to collect data are test questionnaires, interview guidelines and observation sheets.

a. Questionnaire

Questionnaire is a data collection technique by giving a set of questions to respondents to be answered.

b. Test

The test in this study is used to measure the effectiveness of the use of the product being developed. Tests are given twice, namely before the learning process using interactive teaching materials in the form of Pre-test questions and after the learning process using interactive teaching materials in the form of Post-test questions. The results of the two tests are then compared, so there is an improvement between the pre-test and post-test results. The improvement is used to determine the effectiveness of the use of interactive teaching materials in improving the understanding of auditing concepts.

c. Interview guidelines

Interview guidelines are used as a tool to gather information or data from lecturers and students about analyzing student needs. The needs analysis is used as a reference in developing interactive learning module products. Interview activities carried out at the time of pre-observation.

d. Observation

Observation is a tool used to pre-survey conducted in the VII semester students of the Department of Accounting FE-Unimed. Observations were made to collect information related to the analysis of learning needs and conditions both in terms of facilities and infrastructure to support the operation of the product being developed.

\subsection{Data analysis technique}

Data analysis techniques in this study were obtained from research instruments in the form of qualitative and quantitative data. Quantitative data were obtained from questionnaires and qualitative data were obtained from responses or suggestions from experts and students after using interactive teaching materials in the form of interactive learning modules and data analysis techniques for the feasibility of the media using descriptive data analysis. While the quantitative data analyzed as follows:

\section{a. Data Analysis Techniques for Media Feasibility}

1) Questionnaire assessment results obtained from experts (media and material) and student responses in the form of quantitative data are changed in the form of categories with the guidelines in the following table:

Table 1. Scoring

\begin{tabular}{lc}
\hline Category & Score \\
\hline Very good & 4 \\
Good & 3 \\
Bad & 2 \\
Very bad & 1 \\
\hline
\end{tabular}


2) Calculate the average score of instruments using the following formula:

$$
M=\frac{\sum X}{N}
$$

$$
\begin{aligned}
& \text { Note: } \\
& M=\text { Average Score } \\
& \sum \mathrm{X}=\text { Total Score } \\
& \mathrm{N}=\text { Number of Assessors }
\end{aligned}
$$

3) Change the average score into a qualitative value with the following assessment criteria to be a quantitative value.

Table 2. The Criteria of Assessment

\begin{tabular}{ll}
\hline Score Range & Criteria \\
\hline$X \geq M+\mathrm{SBi}$ & Very feasible \\
$M+\mathrm{SBi}>X \geq M$ & Feasible \\
$M>X \geq M-1 \mathrm{SBi}$ & Enough Feasible \\
$X<M-1 \mathrm{SBi}$ & Very Less Feasible \\
Note: & \\
$\mathrm{X}=$ Obtained Score & \\
$\mathrm{M}=$ Average Ideal Score $\mathrm{SBi}=$ Standard Deviation
\end{tabular}

Based on these data, an interactive learning material assessment criteria table can be drawn up in the following table:

Table 3. The Criteria of Determining Score

\begin{tabular}{cll}
\hline Score & Range & Category \\
\hline 4 & $\mathrm{X} \geq 3,0$ & VF (Very feasible) \\
3 & $3,0>\mathrm{X} \geq 2,5$ & $\mathrm{~F}$ (Feasible) \\
2 & $2,5>\mathrm{X} \geq 2,0$ & EF (Enough feasible) \\
1 & $\mathrm{X}<2,0$ & NF (Not feasible) \\
\hline
\end{tabular}

In this study the feasibility value of interactive teaching materials is determined by a minimum value of " $F$ " with the Eligible category. So if the results of the assessment by media experts, material experts and students' responses give the final score "F", then the product development of interactive teaching materials is feasible to use.

\section{b. Data Analysis Techniques of Pre-test and Post-test}

Analysis of the results of the pretest and posttest is done by providing a test problem understanding the concept and measured learning outcomes to see the level of effectiveness of the product. Improvement of student learning outcomes obtained before and after using interactive teaching materials, calculated using the formula $\mathrm{N}$-gain is determined based on the average gain. The gain score (g) obtained is the result of a comparison between the average values pre-test and post-test. The average gain compared ( $\mathrm{N}$-gain) expressed in the following equation: 


$$
g=\frac{S \text { post }-S \text { pre }}{S \text { maks }-S \text { pre }}
$$

Note:

S post: Average score of Posttest

S pre: Average score of Pre-test

S max: Maximum score

Furthermore, if the value is obtained then the next step of the value is converted into the interpretation of the value gain as in the table below:

Table 4. N-gain Interpretation

\begin{tabular}{ccc}
\hline No. & Value $(\mathbf{g})$ & Classification \\
\hline 1 & $(\mathrm{~N}$-gain $) \geq 0,7$ & High \\
2 & $0,7>(\mathrm{N}$-gain $) \geq 0,3$ & Middle \\
3 & $(\mathrm{~N}$-gain $)<0,3$ & Low \\
\hline
\end{tabular}

\section{Analysis}

In this research and development produces products in the form of teaching materials in ATLAS-based Accounting Examination Practice courses. Teaching material product is a digital learning media application that can be used / read on a computer or laptop device. The product development of teaching materials produced through several stages of development based on the Alessi \& Trollip model including the stage of planning, design and the stage of development. Each stage of the research and development can be explained as follows:

\section{Planning Stage}

a. Define the Scope

The selection of program objectives, materials and targets developed in interactive teaching material products is to consider some of the results of observations and interviews with lecturers on accounting examination practices at the FE-Unimed Accounting Department and Practitioners of Public Accountants. Based on the results of preliminary observations obtained some information that supports the selection of material to be developed in this interactive teaching material. According to lecturers of audit practices and Practitioners from the Public Accounting Firm stated that students have difficulty in understanding material that is simulated practice. This can be seen from the way and work attitude of fresh graduates in the Public Accounting Firm.

The practice of checking control tests is one of the materials that are considered difficult for students, because the material is abstract. This difficulty is also supported by the lack of teaching materials used. Teaching Materials used by students are only substantive tests. Where the presentation ofmaterial contained in the book used is very minimal explanation, illustrations are too complicated and not yet interactive which results in students lacking/difficulty understanding concepts. 
b. Identify Learner Characteristic

At this stage, it is to identify the characteristics of students who aim to make the results of product development on target and in accordance with user needs. Identification of student characteristics was obtained from theory, interview results, and preliminary observations at the Department of Accounting FE-Unimed. Characteristics of high school students have an average age of 21-22 years, student motivation to learn increases when using digital form of media, each student has different speeds in understanding the material there are fast, medium, and slow, often answering the teacher's question with short answers, students remember what is seen rather than what is heard and like to imagine and try new things. Based on these characteristics, students need to be facilitated in the development of interactive teaching materials. One of them is using interactive teaching materials that support student speed in learning. For this reason interactive teaching materials are packaged in digital form in which they can present material visually so students are able to imagine and think critically.

c. Produce a Planning Document

The process in this stage is the making of planning documents, consisting of teaching needs, material scripts, test script documents, and assessment documents. The material requirements include the syllabus, Learning Implementation Plan (RPP shortly in Indonesian) and text material in the form of text, and pictures. The test document includes the question grid consisting of pretest and posttest, question exercises, answer keys and discussion of questions. While the assessment documents are in the form of grids and questionnaires for material experts, media experts and student responses.

d. Determine and Collect Resources

At this stage a gathering of supporting resources is carried out in developing interactive teaching material products in the form of software, learning resources, as well as facilities and infrastructure. The process starts from identifying the syllabus in the form of competency standards and basic competencies in accordance with the needs analysis at the time of initial observation and interviews with subject teachers and students. After determining the competency and competency standards, then proceed with the preparation of the lesson plan (RPP). The lesson plans are developed using the assignment method, where these interactive teaching materials will be used independently by students.

Further identification relates to the supporting facilities and infrastructure needed to operate the interactive teaching material products that will be developed. This interactive teaching material product will be in the form of digital that is read on a computer / laptop screen that has a format while the process stages are still based on Microsoft Excel. Based on the observations obtained, there are 28 students having ready-to-use laptops that can be used later. The operating system running on the laptop is Windows.

The next process is related to the content of the material that will be used in interactive teaching material products. In general, material is obtained from various sources such as textbooks and the internet. The material obtained is then designed to be presented in an interactive teaching material product.

e. Conduct Initial Brainstorming

At this stage, the developer conducts discussions with lecturers on audit practices for the breadth of the material aspects, regarding the determination of learning objectives, indicators of goal achievement, sample questions, practice questions, and evaluation questions and so forth. In addition, developers discuss with friends Learning Technology about aspects of developing interactive teaching materials to get advice and input. The process was also consulted with counselors, material experts and the media. 


\subsection{Develop Initial Content Ideas}

The process in this stage is that all ideas are developed. The idea is about the appearance, programming and form of interactive teaching materials that can present text, image, animation, and video content in form of interactive teaching materials that can load content in digital form that can be used / read on computer or laptop.

\section{Conduct Task and Concept Analysis}

At this stage, what is done is to analyze the three dimensional space material obtained from various sources in accordance with the learning objectives that have been determined in the syllabus and lesson plans. The next step is to arrange the scope of the material control test and substantive test according to the learning objectives. In addition, writing the concept map as a flow of material to be studied, lattice questions to measure the achievement of learning objectives, and test scripts in the form of pretest and posttest questions that are used to measure students' understanding of concepts. All documents produced must first be assessed to be appropriate for use when collecting data, so it needs to be consulted with material experts.

\section{Prepare Create Flowchart and Storyboard}

At this stage the design of program planning are carried out in the form of flowcharts and storyboards. Flowchart is a workflow of interactive teaching material products that will be developed when used by student. Furthermore, the preparation of this flowchart is used as the basis for making storyboards that is made to compose a good product design display, color, buttons, text, video, animation and others. In general, the process contained in the storyboard includes a cover page, preface, description, instructions, objectives and concept maps, material description, summary, question exercises, answer keys / discussion of questions and a list of references.

\subsection{Development Stage}

The process in this development phase includes the development of content contained in interactive teaching materials consisting of text, images, animations, practice questions, and videos so that they are easy to read on a computer / laptop or in digital form. Interactive learning material components are the same as module components in general which consist of: cover page, module identity, preface, table of contents, glossary, target users, description, final destination of learning, instructions for learning interactive instructional materials, concept maps, interactive teaching material criteria , learning activities, competency tests, and answer keys. Learning activities that are presented in interactive teaching materials consist of two learning activities, namely learning activity 1 is about the control test. Learning activity 2 is about determining the substantive test. Each learning activity consists of components of learning objectives, material descriptions, summaries, exercises in the form of multiple choice questions, a list of references and key answers / discussion questions.

The product cover page for interactive teaching materials is the title and user identification page. The title page of interactive teaching materials is "ATLAS-based Accounting Examination Practicum. Components of the table of contents, glossary, target users, descriptions, instructions for interactive teaching materials and concept maps are important components in a product. While the table of contents in this interactive teaching material is presented to make it easier for students to access the page as they wish. The interactive teaching material product is equipped with question exercises and answer/discussion questions. Thequestion exercises are presented in each learning activity. The next step support materials, is preparing namely providing user manuals. This manual contains an explanation of the menus contained in interactive teaching materials and learning instructions using interactive teaching materials. 


\section{Results and Discussion}

\section{Alpha Test Results \\ a. Material Expert Validation Results Material}

The validators on interactive teaching material products were conducted by two material experts. Both material experts are lecturers from FE-Unimed accounting majors. The purpose of this material expert validation is to measure the level of accuracy and quality of the material presented in the interactive teaching material product, the substantive test material. In addition, the purpose of this material expert validation is to obtain feasible products from each aspect.

\begin{tabular}{|c|c|c|c|c|c|}
\hline \multirow[t]{2}{*}{ No. } & \multirow{2}{*}{ Aspects } & \multicolumn{2}{|c|}{ Material } & \multirow[t]{2}{*}{ Total } & \multirow[t]{2}{*}{ Average } \\
\hline & & I & II & & \\
\hline 1 & Preliminary & 3.7 & 3.5 & 7.2 & 3.63 \\
\hline 2 & Content & 3.5 & 3.5 & 7 & 3.5 \\
\hline 3 & Learning & 3.5 & 3.5 & 7 & 3.5 \\
\hline 4 & Summary & 3.7 & 3.3 & 7 & 3.5 \\
\hline \multirow[t]{3}{*}{5} & Task & 3.3 & 3.6 & 6.9 & 3.5 \\
\hline & & tal & & 35.1 & \\
\hline & \multicolumn{3}{|c|}{ Total Average } & & $\begin{array}{c}3.526 \\
\text { very feasible }\end{array}$ \\
\hline
\end{tabular}

The results of the assessment of two material experts on the five aspects obtained an average score of 3.52 which is qualitatively categorized as Very Eligible $(X \geq 3.0)$.

\section{b. Media Expert Validation Results Media}

The validator on interactive teaching material products was carried out by two material experts. Both material experts are lecturers from FE-Unimed accounting majors. The purpose of this media expert validation is to measure the level of clarity and utilization of the media used in interactive teaching material products, the accounting examination practice module. In addition, the purpose of this material expert validation is to obtain appropriate media from each aspect.

Table 6. The Result of Both Media Experts' Assessment

\begin{tabular}{|c|c|c|c|c|c|}
\hline \multirow{2}{*}{ No. } & \multirow{2}{*}{ Aspects } & \multicolumn{2}{|c|}{ Media Expert } & \multirow{2}{*}{ Total } & \multirow{2}{*}{ average } \\
\hline & & I & II & & \\
\hline 1 & Display & 3.4 & 3.2 & 6.6 & 3.3 \\
\hline 2 & Preliminary & 3.5 & 3.2 & 6.7 & 3.3 \\
\hline 3 & Utilization & 3.4 & 3.1 & 6.5 & 3.3 \\
\hline 4 & Task/Evaluation & 3.5 & 3.2 & 6.7 & 3.3 \\
\hline \multirow[t]{4}{*}{5} & Summary & 3.8 & 3.2 & 5 & 3.5 \\
\hline & \multicolumn{3}{|c|}{ Total } & 31.5 & \\
\hline & \multicolumn{3}{|c|}{ Average } & & 3.34 \\
\hline & \multicolumn{3}{|c|}{ Category } & & Very feasible \\
\hline
\end{tabular}

The results of the assessment of two media experts on the five aspects obtained a mean score of 3.34 which was qualitatively categorized as Very Eligible $(X \geq 3.0)$. 


\section{Results Pretest and Post Test in Beta 2 Test}

\section{c. Application of Case-Based Learning}

Implementing pretest and posttest aims to determine the level of effectiveness of teaching material products developed in improving understanding of ATLAS-based accounting examination practices, namely by looking at the difference in scores before and after using interactive teaching material products.

$$
g=\frac{S \text { post }- \text { S pre }}{S \text { max }- \text { S pre }}=\frac{17.21}{26.64}=0.65
$$

Based on the above calculation, the score gain obtained from the comparison of the average value of pretest and posttest in learning using interactive teaching materials is 0.65 with the category "Medium" $(0.7 \mathrm{~N}$-Gain $>0.3)$. Theincrease in mean scores posttest indicates that in general interactive teaching materials have been able to improve the understanding of accounting examination practices after students use products in learning.

The pretest and posttest questions used have the same problem language and number of items consisting of 20 items. The 20 items represented by 8 question indicators.

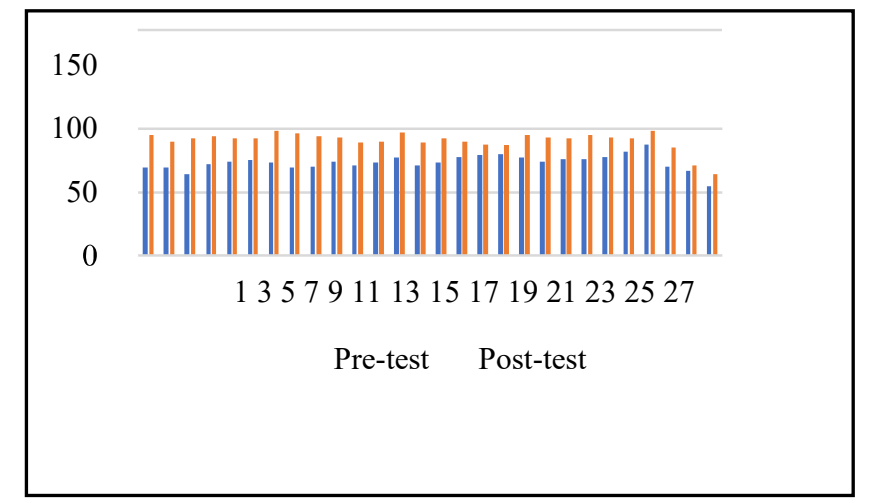

Fig 3. Comparison Results of Average Pretest and Posttest Scores

It can be concluded that the application of Case Base learning can improve students' understanding of ATLAS-based Accounting Examination Practice material with the category "medium" (0.7 $\geq \mathrm{N}-$ Gain $>0.3)$.

\section{Conclusions}

Based on the above calculation, the score gain obtained from the comparison of the average value of pretest and posttest in learning using interactive teaching materials is 0.65 with the category of "Medium" $(0.7 \mathrm{~N}$-Gain $>0.3)$. Improvements to the average scores posttest indicate that in general interactive teaching materials have been able to improve the understanding of accounting examination practices after students use products in learning. 


\section{References}

[1] Komara, E. Belajar dan pembelajaran interaktif. PT. Refika Aditama. Bandung. (2014).

[2] Abdulhak, I. \& Darmawan, E. Teknologi pendidikan. PT Remaja Rosdakarya. Bandung. (2013).

[3] Agoes, Soekrisno. Buku Praktikum Audit. Salemba Empat. Jakarta. (2008).

[4] Amilin. Laboratorium Auditing, $2^{\text {nd }}$ Edition. Universitas Terbuka. Banten. (2014).

[5] Basuki, I \& Haryanto. Assesmen pembelajaran. PT. Remaja Rosdakarya. Bandung. (2015).

[6] Budiningsih, A. C. Karakteristik siswa sebagai pijakan dalam penelitian dan metode pembelajaran. FIP. Yogyakarta. (2011).

[7] Daryanto. Menyusun modul, bahan ajar untuk persiapan guru dalam mengajar. Penerbit Gava Media. Yogyakara. (2013).

[8] Depdiknas. Panduan pengembangan bahan ajar. Dirjen Dikdasmen Direktorat Pembinaan Sekolah Menengah Atas. (2008).

[9] Mulyadi. Buku 2 Auditing, edisi 6. Salemba empat. Jakarta. (2002).

[10] Pusat Pembinaan Profesi Keuangan. Buku Panduan ATLAS. IAPI. Jakarta. (2018).

[11] Rick Hayes et. al. Prinsip-prinsip pengauditan, Edisi 3. Salemba Empat. Jakarta. (2017).

[12] Williem F Messier. Jasa Audit dan Assurance, Edisi 8. Salemba Empat. Jakarta. (2014). 